ISBN 978-93-86878-21-2

18th International Conference on Law, Management, Education, Humanities and Social Sciences

(LMEHSS-18)

Aug. 8-10, 2018 Phnom Penh (Cambodia)

\title{
A Conceptual Approach for Studying the Service Quality Aspects of SolarProject Management
}

\author{
Prof. S. Sundararajan, Dr. K. Sadasivan and Dr. R. Krishnaraj \\ ${ }^{1}$ Professor, School of Management, SRM Institute of Science and Technology(Formerly SRM University), \\ Near Chennai, India
}

\begin{abstract}
With the ever increasing component of services in a Solar Project, there is a need to do Service Quality studies. With the growing complexities of Engineering - Procurement-Construction (E-P-C) route of Solar Projects, the value of services has climbed up to the present level between 30 to 40 of the project cost, progressively, from a level of 10 to $20 \%$, say 20 to 30 years ago.

This situation in turn highlights theplace of a Solar Project in Tangibility Spectrum,[1]which is shifting more towards services and away from Products. Apart from the various Service Quality concepts and Models, SERVQUAL Model[2] by A.Parasuraman et al. and The Gummesson 4Q Model[3] of Offering Quality could be taken up for further surveys and studies, with a view to manage efficiently and effectively, a Solar Project offering.

Service Quality is a function of a range of resources and activities.The aim is to establish any variance in how the different stake holders perceived and rated the various dimensions of service quality during thevarious stages of a Project Life Cycle.By developing organization's own unique service culture and delivering a better quality of service, it should be possible to encourage client loyalty and repeat business.
\end{abstract}

Keywords: Project Management, Service quality, Solar Energy, Tangibility spectrum

\section{Introduction}

\subsection{Sharp focus on Solar Energy:}

Over the next two or three decades, there is a sharp focus of various governments across the globe, towards renewable energy, especially solar energy. The International Solar Alliance (ISA) [4]is an alliance of more than 121 countries, which is a treaties based inter-governmental organization, most of them being sunshine countries, [5] which lie between the Tropic of Cancer and the Tropic of Capricorn. The primary objective of the alliance is to work for efficient exploitation of solar energy and to reduce dependence on fossil fuels. In turn, it has an effect of mitigating the harmful effects of global warming, by reducing the carbon foot print. Solar energy has got a vantage position in the carbon-neutral electricity mix.

\subsection{Solar Projects}

India has pledged a target of installing 100GW Solar Projects by 2022 and reduction in emission intensity by $33-35 \%$ by 2030 to let solar energy reach to the most unconnected villages and communities and also towards creating a clean planet.Further, ISA is planning for an investment level of USD one trillion in the next two decades.[6]The carbon di oxide emission, on a conventional Thermal Project of 1000MW capacity is roughly $900 \mathrm{~g}$ for every kWh energy generated.[7] In case of Solar power generation, it is around 54-60 grams per KWH.

\subsection{Role of service in Solar Projects and its place in Tangibility Spectrum:}

If we look at the Tangibility Spectrum for projects, it may involve around $70 \%$ of products and $30 \%$ of services. Project Management (PM) of Solar Projects faces the challenge of managing them efficiently and 
effectively, so that the project shall remain economically attractive and competitive in the market. Service Quality can be a dimension which could add a strategic advantage to PM. Please refer to Fig.1TheGummesson's 4Q Model of Offering Quality reproducedhere.

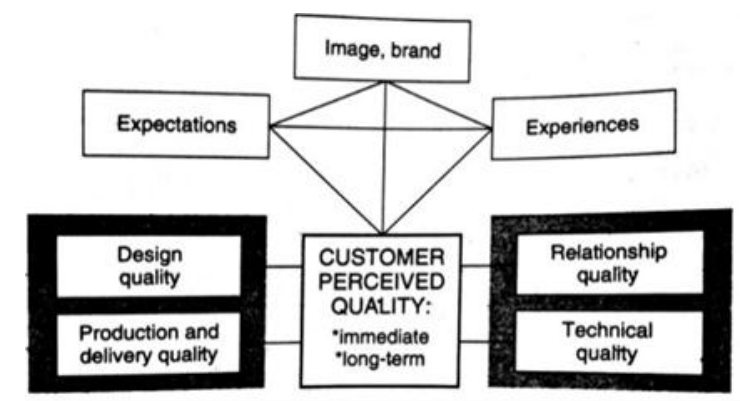

Fig.1TheGummesson's 4Q Model of Offering Quality”

\subsection{Solar Projects and Project Management today:}

The five dimensions of Service Quality, namely Responsiveness, Assurance, Tangibles, Empathy and Reliability, popularly referred to as RATER Model[8] or SERVQUAL Model by A.Parasuraman et al. could be applied in achieving strategic advantage in PM, in an innovative manner. The Service Components of a modern Solar Photo Voltaic (PV) Project could be carefully identified and subjected to Service Quality studies to achieve excellence in efficiently and effectively managing the same.

\section{Dimensions of Product Quality versus Dimensions of ServiceQuality:}

While Garvin's eight dimensions of Product Quality namely, Performance, Features, Reliability, Conformance, Durability, Serviceability, Aesthetics and Perceived Quality would play a significant part of Product Component, the five dimensions of Service Quality would play a significant role on the Service components of a Solar Project.

\section{Technical Quality versusFunctional quality:}

Christian Gronroos[9] views on understanding the Total Perceived Quality by strengthening Technical Quality (What component) and Functional Quality (Why component) could also be important. Please see the Fig.2 Total Perceived Quality Model by Gronroos.C."

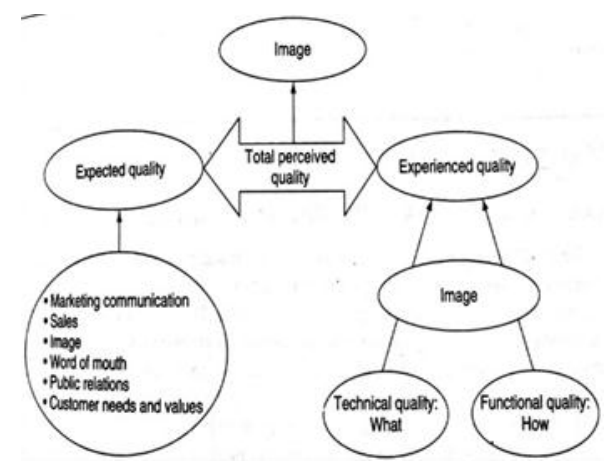

Fig.2 Total Perceived Quality by Christian Gronroos 


\section{The Quality Trilogy:}

Dr. Joseph M. Juran's Quality Trilogy propounded in 1986, which involves Quality Planning, Quality Control and Quality Improvement has found more practitioners in the construction industry too. Here we could study the different aspects of Grid Connected as well as Off-grid PV Solar Projects.

\section{Identifying the Service components of a Solar Project, while adopting the E-P- CRoute:}

The various Service Components of a Solar Project are Technical Design Specifications, choice of Solar cell material technology, Construction \& Fabrication, Procurement, Supply Chain Management, Relationship Management, Repair and Maintenance, Regular Testing, Monitoring and Inspection Services, Planned Maintenance, Predictive Maintenance, Preventive Maintenance, Break Down Maintenance and Autonomous Maintenance Services, Electrical Grid connectivity Operation and Maintenance Services, Battery Storage and Inverter Facilities, Solar Panel Tracking and Data Analysis etc.

\section{Significance of Service Quality in Projects:}

In today's competitive climate, service quality is an effective tool to enhance the firm's position in the market place (Baron and Harris, 1995). It should be seen as the prime cause of client satisfaction and the appropriate way to create or sustain a competitive advantage, and building a strong and lasting relationship with clients(Preece and Moodley 1996, Preece and Tarawneh 1996)[11]. Service Quality may be the vehicle forcontractors to differentiate themselves from their competitors.

\section{The Significance of Service Performance:}

SERVPERF[12] scale is a twenty-two item survey instrument used to assess non-electronic service quality based on perceptions of actual service quality, after the service experience. The instrument includes five dimensions: reliability, assurance, tangibles, empathy, and responsiveness, which is the mainstay of SERVQUAL Model. Adapting the SERVQUAL scale to the measurement context improves its predictive validity; conversely, the predictive validity of SERVPERF is not improved by context adjustments. In addition, measures of services quality[13] gain predictive validity when used in less individualistic cultures, non - English speaking countries, and industries with an intermediate level of customization. The studies on service quality aspects of Supply Chain/purchasing [14] can throw light in our studies regarding the service quality aspects of a Solar Project execution, adopting the Engineering - Procurement - Construction route.

\section{Conclusion}

Solutions to bridge the gap between ecology and economy exist everywhere.United Nations, under the Sustainable Developmental Goals (SDGs) and also under SDG- 7: "Ensure access to affordable, reliable, sustainable and modern energy for all" supports Solar Power Projects around the globe.

Entry of disruptive technologies cannot be ruled out in the energy sector. It calls for VUCA Approach [10] (Volatility, Uncertainty, Complexity and Ambiguity) and various other sophisticated management tools, Models and inputs, to manage the scenario, with professional excellence.With increasing de-carbonization, lesser dependence on fossil fuels, more emphasis on renewable and a firm focus on solar, integrating professional management with superior Engineering \&Technology, will become increasingly imperative.

Solar Project Management is a young and growing field, offering immense scope for Management Research in the very near future. 


\section{References}

[1] G.LynnShostack, "Breaking Free from Product marketing”, Journal of Marketing 41 (April 1977), pp. 73-80 https://doi.org/10.2307/1250637

[2] Servqual: A Multiple-Item Scale For Measuring Consumer Perceptions of Service Quality Parasuraman, A; Zeithaml, Valarie A; Berry, Leonard L. Journal of Retailing; Greenwich Vol. 64, Iss. 1, (Spring 1988)

[3] Gummesson.E., "The Gummesson 4Q Model of Offering Quality", Quality Management in Service Organizations, New York: ISQA International Service Quality Association,1993 p.229

[4] Working Paper on International Solar Alliance (ISA)P.1-11, Nov. 2015

[5] PM Modi's vision to unite 'Surya Putra Nations' moulds into organisation to produce solar energy Source: News Bharati Date: 06-Dec.2017

[6] Solar Summit of March 2018, organized by ISA.

[7] Central Electricity Authority (CEA). "Performance Review of Thermal Power Stations" 2016, New Delhi -11006.

[8] Alternate name for SERVQUAL Model -- Parasuraman, A., Zeithaml, V. A., \&Berry, L. L. (1988). SERVQUAL: A multiple-item scale for measuring consumer perceptions of service quality. Journal of Retailing, 64, 12-40.

[9] Christian Gronroos, “A Service Quality Model and its Marketing Implications”,European Journal of Marketing, 18(4), 1984, P.36-44 https://doi.org/10.1108/EUM0000000004784

[10] Nathan Bennett and James Lemomine, “What VUCA really means for you?” Harvard Business Review, Jan. Feb. 2014 Issue

[11] Project Managers' Service Quality For Client Satisfaction On Design \& Build Projects, Christopher Preece and Sultan Tarawneh, Construction Management Group, Department Of Civil Engineering, University Of Leeds, UK13th Annual ARCOM Conference, 15-17 September 1997, King's College,Cambridge. Association of Researchers in Construction Management, Vol. 1, 264-74.

[12] Fernando Jaramillo, Jay P. Mulki, (2007) "The validity of the SERVQUAL and SERVPERF scales: A meta - analytic view of 17 years of research across five continents", International Journal of Service Industry Management, Vol. 18 Issue: 5, pp.472-490

[13] Cronin J. Joseph,Jr.Taylor, Steven ,"Measuring Service Quality: A Reexamination and Extension”, A Journal of Marketing; Jul 1992;p.55- 56

[14] L.L. Stanley, J.D. Wisner, "Service quality along the supply chain: implications for purchasing”, Journal of Operations Management 19 (2001)P. 287-306 https://doi.org/10.1016/S0272-6963(00)00052-8

\section{About First Author}

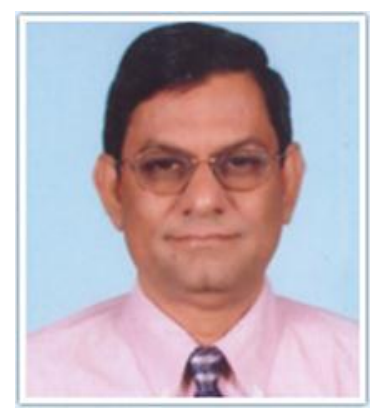

Prof. S. Sundararajan was born at Chennai in India in 1955.He did his Bachelor of Engineering in Electrical and Electronics Engineering from National Institute of Technology, Trichy, India. He pursued his Master of Business Administration from Pondicherry University, Pondicherry India with a University Rank. He is now Professor, School of Management, Faculty of Management, SRM Institute of Science and Technology (SRMIST)(Formerly SRM University), at Kattankulathur Campus, India since July 1999. Earlier he served as Associate Professor at New College Institute of Management, Chennai, India. He brings with him two decades of rich Corporate experience with Indian Companies as well as Multinational Corporations. 
Prof. Sundararajan also has an additional 19 years of experience in teaching Management. His current areas of Research interests include Service Quality, Total Quality Management and certain Service Marketing issues of futuristic impact. At present he is working on his Doctoral thesis on Service Quality Area.

Prof. Santanagopalan has been a delegate at Three international conferences at Hongkong in 2012, Chulalongkorn University, Bangkok in 2016 and UNESCO Conference at Manila, Philippines in Oct. 2017.

\section{About Second Author}

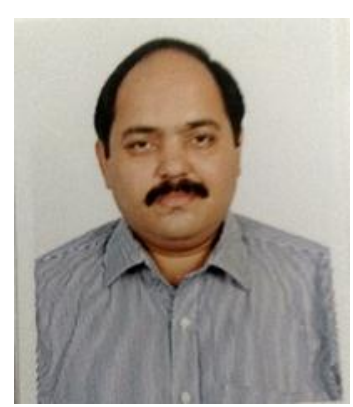

Indexed Journals.

Dr. K. Sadasivan was born in Chennai in 1968. He did Bachelor of Engineering in Mechanical Branch from University of Madras in 1990, Master of Business Administration in Marketing and Operations in June 1992 from Annamalai University and $\mathrm{PhD}$ in Marketing from SRM University in Aug.2012.

Dr. Sadasivan has 22 years teaching Experience at SRM University apart from 11years as an Entrepreneur, operating successfully a manufacturing unit in the Small Scale Industries sector as well as 4 years experience in Industrial Marketing Profession. His research interests are Brand Management and Quality Management.

Dr. Krishnamurthy has 17 publications in International Journals including SCOPUS

\section{About Third Author}

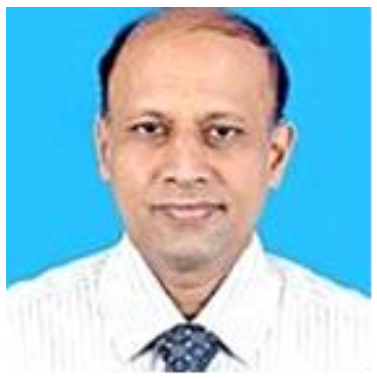

Dr. R. Krishnaraj was born in Srivilliputhur,Tamilnadu, India.His date of Birth IS 28-07-1967. He has been AwardedPh.D. (Management) by Bharathidasan University, India in February 2009. His Major Filed of Study is marketing strategies.

Dr. Krishnaraj has around 20 years of industrial experience and Nine years of academic experience. He is now Associate Professor, Faculty of Management,SRMIST, Kattankulathur, Tamil Nadu, India. He has published around sixty journal articles and one book. The title of the latest journal article is Employee triggered information security risks- a critical corporate challenge, International Journal of Information Security, 2018 as co-author. He has published a book with the title of Pharmaceutical Marketing Strategies by Lambert Academic Publishers, Germany, 2013. Under his guidance, six scholars were awarded Ph.D., in Management. His current research interest is challenges in services marketing.

Dr. Ramanujam is a member of University Research Coordination Committee, SRMIST, Tamil Nadu, India. 